\title{
MENINGKATKAN HASIL BELAJAR PESERTA DIDIK PADA SPLIT CLASS MELALUI PEMBELAJARAN LANGSUNG BERBANTUAN VIDEO INTERAKTIF TURUNAN
}

\author{
Laily Wijayanti Utami ${ }^{1}$, Subanji ${ }^{2}$ \\ 1,2 Program Studi S2 Pendidikan Matematika, Universitas Negeri Malang, ${ }^{1}$ SMAN 5 Pamekasan \\ Email: laily.wijayanti.1903117@students.um.ac.id
}

\begin{abstract}
Abstrak:
Pandemi covid-19 telah memaksa SMA Negeri 5 Pamekasan untuk menyesuaikan pola pembelajaran, separuh kelas mengikuti pembelajaran tatap muka di sekolah dan separuhnya lagi mengikuti pembelajaran daring dari rumah, yang disebut split class. Penelitian ini bertujuan mendeskripsikan pembelajaran langsung berbantuan video interaktif turunan yang dapat meningkatkan hasil belajar. Penelitian ini dilakukan dalam 2 siklus, masing-masing siklus berisi tahap persiapan, pelaksanaan, observasi dan refleksi. Subjek penelitian ini adalah 26 peserta didik kelas XI MIPA 1 SMA Negeri 5 Pamekasan. Pembelajaran langsung berbantuan video interaktif turunan pada materi turunan dilakukan dengan langkah: (1) Menyampaikan tujuan dan mempersiapkan peserta didik (2) Mendemonstrasikan pengetahuan dan keterampilan dengan video pembelajaran interaktif turunan (3) Membimbing pelatihan dengan LKPD terbimbing (4) Mengecek pemahaman dan memberikan umpan balik dan (5) Memberikan kesempatan untuk pelatihan lanjutan dan penerapan. Hasil penelitian penerapan pembelajaran langsung berbantuan video pembelajaran turunan menunjukkan peningkatan persentase ketuntasan belajar peserta didik dari siklus 1 ke siklus 2. Pada siklus 1 persentase ketuntasan peserta didik adalah $65,2 \%$, sedangkan pada siklus kedua mengalami kenaikan menjadi 86,9\%. Persentase hasil observasi ketercapaian pelaksanaan pembelajaran mengalami peningkatan sebesar $15 \%$ dengan kriteria pada masing-masing siklus bernilai sangat baik.
\end{abstract}

Kata Kunci: Hasil Belajar, Pembelajaran Langsung, Media Video Pembelajaran Turunan

\begin{abstract}
:
The Covid-19 pandemic has forced SMA Negeri 5 Pamekasan to adjust learning patterns, half of the class is taking face-to-face learning at school and the other half is taking online learning from home, which is called split class. This study aims to describe direct learning assisted by interactive video derivatives that can improve learning outcomes. This research was conducted in 2 cycles, each cycle contains the stages of preparation, implementation, observation and reflection. The subjects of this study were 26 students of class XI MIPA 1 SMA Negeri 5 Pamekasan. Direct learning assisted by derivative interactive videos on derived material is carried out in the following steps: (1) Delivering goals and preparing students (2) Demonstrating knowledge and skills with derivative interactive learning videos (3) Guiding training with guided LKPD (4) Checking understanding and providing feedback feedback and (5) Provide opportunities for further training and implementation. The results of the study on the application of direct learning assisted by derived learning videos showed an increase in the percentage of students' learning mastery from cycle 1 to cycle 2 . In cycle 1 , the percentage of student mastery was $65.2 \%$ while in the second cycle it increased to $86.9 \%$. The percentage of observation results on the achievement of learning implementation has increased by $15 \%$ with the criteria in each cycle being very good.
\end{abstract}

Keywords: Learning outcomes, Direct Learning, Derivative Learning Video Media

\section{Pendahuluan}

Pembelajaran matematika

merupakan pembelajaran yang kurang disenangi oleh peserta didik. Beberapa hal yang membuat peserta didik kurang menyukai pembelajaran matematika 
diantaranya matematika dianggap sulit, matematika dianggap membosankan dan selalu berhubungan dengan angka. Salah satu faktor tersebut mengakibatkan peserta didik kesulitan dalam belajar matematika yang berakibat pada rendahnya hasil belajar peserta didik. Hasil belajar menurut Fimansyah (2015) hasil akhir yang dimiliki atau diperoleh peserta didik setelah mengalami proses belajar matematika yang ditandai dengan skala nilai berupa huruf atau simbol atau angka, dan hal ini biasa dijadikan tolak ukur berhasil atau tidaknya peserta didik tersebut dalam pembelajaran matematika. Sedangkan menurut Muslina (2017) hasil belajar merupakan kemampuan yang akan dimiliki oleh peserta didik setelah mengikuti pembelajaran matematika. Pendapat lain tentang hasil belajar yaitu Nurrita (2018) hasil belajar adalah hasil yang diberikan kepada siswa berupa penilaian setelah mengikuti proses pembelajaran dengan menilai pengetahuan, sikap, ketrampilan pada diri siswa dengan adanya perubahan tingkah laku. Pendapat lain tentang. Dari beberapa pendapat diatas dapat disimpulkan bahwa hasil belajar merupakan kemampuan yang dimiliki oleh peserta didik setelah mengikuti proses pembelajaran matematika berupa nilai sikap keterampilan dan pengetahuan ditandai dengan adanya perubahan tingkah laku.

Tujuan pembelajaran matematika diantaranya peserta didik diharapkan memiliki kompetensi dari segi pengetahuan, sikap dan keterampilan. Tujuan tersebut bisa tercapai peserta didik dan pendidik berperan aktif dalam pembelajaran serta didukung oleh lingkungan belajar yang kondusif di sekolah. Adanya pandemi covid-19 mengakibatkan beberapa sekolah yang berada dalam zona hijau diizinkan untuk mengadakan pembelajaran tatap muka terbatas. Pembelajaran tatap muka terbatas dilakukan di SMAN 5 Pamekasan dengan membagi separuh jumlah peserta didik dalam satu kelas untuk mengikuti pembelajaran tatap muka di sekolah sedangkah separuh jumlah peserta didik melakukan pembelajaran daring dari rumah dalam hal ini penulis menyebutnya Split Class.
Pembelajaran yang dilakukan dalam Split Class yaitu separuh jumlah siswa mengikuti pembelajaran tatap muka di sekolah saparuhnya lagi mengikuti pembelajaran daring dari rumah melalui Google Classroom dan WhatsApp Grup. Hal tersebut dilakukan secara bergantian setiap satu minggu sekali adapun dalam satu kali pertemuan tatap muka dalam 1 jam pelajaran hanya dibatasi waktu 30 menit. Salah satu dampak negatif dalam pembelajaran matematika diantarannya kurangnya semangat dan motivasi peserta didik dalam pembelajaran matematika yang mengakibatkan rendahnya hasil belajar. Pendidik juga dituntut untuk lebih berinovasi agar pembelajaran dalam Split Class tetap berjalan secara optimal.

Berdasarkan hasil observasi pada saat pembelajaran dilakukan secara tatap muka terbatas dalam split class dan wawancara dengan guru Matematika di SMA Negeri 5 Pamekasan serta pengalaman peneliti saat mengajar, peserta didik mempunyai tingkat pengetahuan, kemampuan dan motivasi belajar yang bervariasi. Ketika proses pembelajaran banyak peserta didik yang tidak memperhatikan pembelajaran, tidak mencatat pelajaran, dan hasil belajar yang masih rendah. Hal tersebut karena proses pembelajaran kurang menarik minat peserta didik dan keterbatasan media pembelajaran. Pembelajaran tersebut membuat peserta didik kurang mandiri, pasif dalam kegiatan belajar mengajar dan kurang menguasai materi sehingga berpengaruh terhadap hasil belajar peserta didik yang kurang optimal.

Model pembelajaran yang dinilai meningkatkan motivasi dan semangat peserta didik pada saat pembelajaran tatap muka terbatas salah satunya adalah pembelajaran langsung. Pembelajaran langsung (direct learning) merupakan model pembelajaran langsung merupakan model pembelajaran yang dirancang untuk menunjang terlaksananya proses belajar setiap peserta didik yang erat kaitannya dengan pengetahuan prosedural dan pengetahuan deklaratif yang terprogram dengan baik dan dapat dipraktikkan dengan pola kegiatan secara bertahap, selangkah demi selangkah (Iza, 2014). Panjaitan 
(2017) menyebutkan bahwa Pembelajaran langsung memerlukan perencanaan dan pelaksanaan yang sangat hati-hati dipihak guru. Agar efektif, pembelajaran langsung mensyaratkan tiap detik keterampilan atau isi didefenisikan secara seksama, demonstrasi, dan jadwal pelatihan dilaksanakan secara bersama. Dengan penerapan pembelajaran langsung tersebut diharapkan dapat meningkatkan motivasi belajar peserta didik dan juga hasil belajar.

Beberapa penelitian sebelumnya menyebutkan bahwa pembelajaran langsung dapat meningkatkan hasil belajar peserta didik yaitu (Iza dkk., 2014), (Winanto dkk., 2015), (Panjaitan, 2017), (Sutjiningtyas, 2018) dan (Sugita, 2020). Menurut (Julianto, 2011) kelebihan dari model pembelajaran langsung sebagai berikut: 1) Menggunakan metode ceramah sekaligus demonstrasi yang memudahkan siswa untuk memahami materi yang disampaikan, 2) Melatihkan dua pengetahuan secara bertahap yakni keterampilan prosedural dan keterampilan deklaratif, 3) Sesuai untuk pembelajaran berorientasi pada keterampilan. Dalam model pembelajaran langsung terdapat lima fase yang sangat penting. Pembelajaran langsung dapat berbentuk ceramah, demonstrasi, pelatihan/praktek, dan kerja kelompok.

Upaya lain yang bisa dilakukan untuk meningkatkan motivasi dan hasil belajar peserta didik yaitu melalui media pembelajaran. Menurut (Munadi, 2013) media pembelajaran adalah segala sesuatu yang dapat menyampaikan dan menyalurkan pesan dari sumber secara terencana sehingga tercipta lingkungan belajar yang kondusif dimana penerimanya dapat melakukan proses belajar secara efisien dan efektif. Media pembelajaran yang inovatif merupakan alat untuk menyampaikan informasi belajar dan pesan dengan memanfaatkan kemajuan teknologi dan informasi, sehingga peserta didik dapat memahami materi yang disampaikan oleh pendidik menjadi lebih mudah. Media pembelajaran inovatif salah satunya adalah video pembelajaran, adanya video pembelajaran diharapkan mampu meningkatkan motivasi peserta didik dalam pembelajaran matematika. Video pembelajaran sangat membantu pada saat pembelajaran dilakukan secara tatap muka terbatas pada split class yaitu dapat memudahkan penyampaian materi kepada peserta didik baik dikelas luring maupun kelas daring (belajar dari rumah).

Pembelajaran dengan menggunakan video dapat mendorong dan meningkatkan motivasi peserta didik sehingga membuat peserta didik lebih ingat terhadap materi (Kustandi \& Sutjipto, 2013). Kajian tentang efektifitas penggunaaan media video pembelajaran pernah dilakukan oleh beberapa peneliti yaitu (Bravo et al., 2011), (Altunisik, 2013), (Adesote \& Fatoki, 2013), (Fish dkk., 2016), (Miftahussurur \& Pramono, 2016), (Wulandari et al., 2017), (Tasmalina \& Prabowo, 2018), (Ardiansah, 2018), (Aniq \& Karyaningrum, 2018), (Khairani dkk., 2019) dan (Dzara et al., 2020). Dari beberapa penelitian tersebut diperoleh kesimpulan bahwa penggunaan video pembelajaran sangat efektif untuk meningkatkan motivasi dan hasil belajar peserta didik. Video yang diberikan oleh pendidik bisa digunakan dan dibuka kapanpun oleh peserta didik, memudahkan pendidik dalam penyampaian materi pembelajaran serta membantu peserta didik dalam memahami materi sehingga dapat meningkatkan hasil belajar.

Adanya berbagai permasalahan yang muncul saat pembelajaran dilakukan secara tatap muka terbatas pada split class yaitu kurangnya motivasi saat pembelajaran dan rendahnya hasil belajar serta beberapa paparan peneliti sebelumnya tentang efektifitas penerapan model pembelajaran langsung berbantuan video pembelajaran yang dapat meningkatkan hasil belajar peserta didik maka peneliti mengadakan penelitian dengan judul "Meningkatkan Hasil Belajar Peserta Didik pada Split Class melalui Pembelajaran Langsung berbantuan Video interaktif Turunan".

\section{Metode Penelitian}

Penelitian yang dilakukan merupakan penelitian tindakan kelas (PTK), tujuan penelitian ini untuk mendeskripsikan pembelajaran langsung berbantuan video interaktif turunan yang dapat meningkatkan 
hasil belajar. Subjek peneltian adalah peserta didik kelas XI MIPA 1 SMAN 5 Pamekasan tahun pelajaran 2020/2021 yang berjumlah 26 peserta didik. Peserta didik laki-laki berjumlah 4 dan peserta didik perempuan berjumlah 22. Alasan pemilihan subjek penelitian adalah pada kelas tersebut belum memenuhi kriteria ketuntasan secara klasikal yaitu masih dibawah $80 \%$. Adanya penerapan pembelajaran langsung berbantuan video interaktif turunan diharapkan mampu meningkatkan ketuntasan belajar secara klasikal dan meningkatkan rata-rata hasil belajar peserta didik secara individu.

Proses pembelajaran pada
penelitian ini dilakukan dengan model
pembelajaran langsung, Sintaks model
pembelajaran langsung (direct learning)
yang digunakan mengacu pada (Nur, 2011)
yaitu: 1). Menyampaikan tujuan dan
mempersiapkan peserta didik, 2)
Mendemonstrasikan pengetahuan dan
keterampilan 3) Membimbing pelatihan, 4)
Mengecek pemahaman dan member umpan
balik, 5) Memberikan kesempatan untuk
pelatihan lanjutan. Berikut ini tabel sintaks
modifikasi pembelajaran langsung
berbantuan video pembelajaran turunan
pada split class:

Tabel 1.Sintaks Modifikasi Pembelajaran Langsung.

\begin{tabular}{|c|c|}
\hline Langkah & Aktivitas Guru \\
\hline $\begin{array}{l}\text { Langkah } 1 \\
\text { Menyampaikan tujuan dan } \\
\text { mempersiapkan peserta didik }\end{array}$ & $\begin{array}{l}\text { - Menjelaskan topik, informasi latar belakang pelajaran, } \\
\text { dan mempersiapkan untuk belajar. }\end{array}$ \\
\hline $\begin{array}{l}\text { Langkah } 2 \\
\text { Mendemonstrasikan pengetahuan } \\
\text { dan keterampilan dengan video } \\
\text { interaktif turunan. }\end{array}$ & $\begin{array}{l}\text { - Mendemonstrasikan keterampilan dengan benar atau } \\
\text { mnyajikan inforrmasi tahap demi tahap melalui video } \\
\text { interaktif turunan }\end{array}$ \\
\hline $\begin{array}{l}\text { Langkah } 3 \\
\text { Membimbing pelatihan } \\
\text { Langkah } 4 \\
\text { Mengecek pemahaman dan memberi } \\
\text { umpan balik }\end{array}$ & $\begin{array}{l}\text { - Merencanakan dan memberi bimbingan pelatihan awal } \\
\text { dengan memberikan LKPD terbimbing } \\
\text { - Mengecek apakah peserta didik telah berhasil melakukan } \\
\text { tugas dengan baik dan memberikan umpan balik }\end{array}$ \\
\hline $\begin{array}{l}\text { Langkah } 5 \\
\text { Memberikan kesempatan untuk } \\
\text { pelatihan lanjutan }\end{array}$ & $\begin{array}{l}\text { - Mempersiapkan kesempatan melakukan pelatihan } \\
\text { lanjutan dengan perhatian khusus pada penerapan kepada } \\
\text { situasi lebih kompleks dalam kehidupan sehari hari. }\end{array}$ \\
\hline
\end{tabular}

Penelitian ini dilaksanakan dalam 2 siklus dengan masing-masing siklus ada 2 kali pertemuan, serta di akhir setiap siklus diadakan tes untuk mengukur peningkatan hasil belajar peserta didik. Masing-masing siklus terdiri dari empat tahap yaitu perencanaan, tindakan, observasi dan refleksi. Pada tahap perencanaan dilakukan penyusunan Perangkat Pembelajaran yaitu RPP, LKPD, Video Pembelajaran Turunan, instrument penilaian dan lembar observasi. Tahap selanjutnya pelaksanaan tindakan, dilakuan dengan melaksanakan kegiatan pembelajaran sesuai RPP pada split class. Rancangan pembelajaran disusun sesuai sintaks pembelajaran langsung .

Proses observasi dilakukan pada split class dilakukan dengan mengamati pelaksanaan proses pembelajaran sesuai dengan tahapan model pembelajaran langsung. Hasil observasi yang dilakukan oleh observer terhadap keterlaksanaan pembelajaran dihitung persentase rata-rata untuk menetukan kriteria keterlaksanaan pembelajaran yang telah dilakukan. Kriteria keterlaksanaan pembelajaran, meliputi sangat kurang $(\leq 20)$, kurang $(21-40)$, cukup (41-60), baik (61-80), sangat baik (81-100). Tahap terakhir yaitu refleksi dilakukan dengan menganalisis keterlaksanaan proses pembelajaran sesuai dengan sintaks model pembelajaran langsung dan penigkatan hasil belajar peserta didik dari siklus I ke siklus II. Pembelajaran Langsung berbantuan video interaktif turunan pada split class dikatakan berhasil apabila keterlaksanaan pembelajaran mencapai kriteria sangat baik, serta ada peningkatan hasil belajar peseta didik. 


\section{Hasil dan Pembahasan \\ Hasil}

Siklus I

Siklus I dilakukan dalam dua kali pertemuan yaitu pada rabu tanggal 17 Maret 2021 membahas materi definisi turunan fungsi dan rabu 24 Maret 2021 membahas sifat-sifat turunan fungsi. Masing- masing pertemuan pada split class dibagi menjadi dua bagian yaitu kelas luring dan kelas daring. Untuk kelas luring pembelajaran yang dilakukan didalam kelas secara tatap muka menggunakan fase-fase pembelajaran langsung sedangkan pada kelas daring dilakukan secara online melalui WhatsApp grup kelas dengan cara mengirimkan link video dan LKPD kepada peserta didik.

Proses pembelajaran pada kelas luring pertemuan pertama dilakukan sesuai sintaks pembelajaran langsung yaitu langkah pertama menyampaikan tujuan dan mempersiapkan peserta didik, kegiatan yang dilakukan pada langkah pertama yaitu dengan apersepsi dan motivasi serta menjelaskan informasi tentang materi, latar belakang, tujuan pembelajaran dan mempersiapkan peserta didik untuk belajar. Langkah kedua yaitu mendemonstrasikan pengetahuan dan keterampilan dengan video interaktif turunan. Pada langkah kedua ini peserta didik mengamati video interaktif tentang turunan yang sudah dipersiapkan oleh guru, video pembelajaran tersebut berisi tentang masalah kontekstual tentang turunan, penjelasan materi definisi dan sifat turunan serta contoh soal dan latihan soal. Langkah ketiga yaitu membimbing pelatihan, diawali dengan memberikan LKPD terbimbing kepada tiap kelompok. Guru memberikan bimbingan kepada masing-masing kelompok yang memerlukan bimbingan. Langkah keempat mengecek pemahaman dan memberi umpan balik dilakukan dengan mengecek hasil diskusi kelompok peserta didik dalam menyelesaikan LKPD apakah sudah melaksanakan tugas dengan baik atau belum. Selanjutnya memberikan kesempatan kepada perwakilan masingmasing kelompok untuk mempresentasikan hasil diskusi pengerjaan LKPD. Kelompok yang lain memberikan tanggapan pada presentasi. Langkah terakhir yaitu memberikan kesempatan untuk pelatihan/bimbingan lanjutan. Bimbingan lanjutan dilakukan jika peserta didik masih mengalami kesulitan tentang materi definisi turunan dan sifatnya. Langkah pembelajaran luring pada pertemuan kedua sama dengan langkah pembelajaran pertemuan pertama.

Proses pembelajaran pada kelas daring pertemuan pertama dilakukan melalui whatsApp grup kelas diawali dengan memberikan motivasi kepada peserta didik untuk tetap semangat meskipun pembelajaran dilakukan secara daring. Selanjutnya guru memberikan informasi tentang materi yang akan dipelajari dan membagikan link video yang sebelumnya sudah diunggah lewat youtube. Guru memberikan kesempatan untuk bertanya jika ada materi, contoh soal atau latihan soal yang masih belum dimengerti pada video pembelajaran. Jika tidak ada pertanyaan maka peserta didik melanjutkan dengan mengerjakan LKPD yang sudah dikirim melalui whatsapp secara mandiri. Hasil pekerjaan peserta didik berupa LKPD dan latihan soal kemudian difoto dan dikirimkan kepada guru melalui WhatsApp. Langkah pembelajaran daring pada pertemuan kedua sama dengan langkahlangkah pada pertemuan pertama

Secara garis besar proses pembelajaran siklus I pada split class tidak banyak mengalami banyak kendala pada pembelajaran luring akan tetapi pada kelas daring masih ada beberapa peserta didik yang kurang merespon dalam whatApp grup dan terlambat dalam pengumpulan tugas. Pada kelas luring pembelajaran berjalan sesuai rencana dan sintaks pembelajaran langsung, hanya saja pada pertemuan kedua ada satu soal dalam LKPD yang rata-rata beberapa kelompok mengalami kesulitan sehingga perlu bimbingan dan penjelasan dari guru yaitu tentang sifat pembagian dalam turunan. Setelah adanya bimbingan lanjutan dari guru peserta didik menjadi lebih mengerti dan faham tentang sifat pembagian dalam turunan.

Pada akhir pertemuan kedua dilakukan tes akhir siklus untuk mengetahui hasil belajar peserta didik pada siklus I baik 
dalam kelas daring mapun luring, tes akhir siklus berupa soal uraian sehingga dapat mengukur tingkat pemahaman peserta didik. Berdasarkan hasil tes akhir siklus dan hasil observasi diperoleh hasil sebagai berikut:

Tabel 2. Hasil Belajar dan Persentase Keterlaksaan Pembelajaran

\begin{tabular}{lc}
\hline Nilai terendah & 55 \\
\hline Nilai tertinggi & 87 \\
\hline Jumlah peserta didik belum tuntas & 15 \\
\hline Jumlah peserta didik belum tuntas & 8 \\
\hline Rata-rata & 74,5 \\
\hline Persentase ketuntasan belajar & $65,2 \%$ \\
\hline Persentase keterlaksanaan pembelajaran & $80 \%$ \\
\hline
\end{tabular}

Berdasarkan tabel hasil belajar peserta didik pada siklus I diperoleh data nilai rata-rata hasil belajar 74,5 dengan persentasi ketuntasan belajar $65,2 \%$. Hasil tersebut belum maksimal dan belum mencapai kriteria yang ditentukan sehingga diperlukan perbaikan pada siklus selanjutnya agar hasil belajar dan persentase belajar sesuai yang diharapkan. Perbaikan yang akan dilakukan terdapat pada tabel berikut:

Tabel 3. Hasil Refleksi siklus I

\begin{tabular}{|c|c|c|}
\hline Kendala & Penyebab & Perbaikan \\
\hline Kelas Luring & & \\
\hline $\begin{array}{l}\text { Peserta didik masih belum } \\
\text { percaya diri ketika } \\
\text { mengerjakan tes sehingga } \\
\text { masih menanyakan } \\
\text { jawaban dari peserta didik } \\
\text { lain }\end{array}$ & $\begin{array}{l}\text { - Peserta didik } \\
\text { kurang percaya } \\
\text { diri }\end{array}$ & $\begin{array}{l}\text { - Guru memotivasi peserta didik } \\
\text { untuk dapat mengerjakan tes } \\
\text { dengan hasil usaha sendiri. } \\
\text { Memberikan apresiasi kepada } \\
\text { peserta didik untuk melakukan test } \\
\text { secara jujur, sehingga peserta didik } \\
\text { lebih percaya diri pada saar } \\
\text { mengerjakan test }\end{array}$ \\
\hline $\begin{array}{l}\text { Tidak semua peserta } \\
\text { didik berperan aktif } \\
\text { dalam kegiatan diskusi } \\
\text { dan presentasi kelompok. }\end{array}$ & $\begin{array}{l}\text { - } \text { Metode } \\
\text { pembelajaran } \\
\text { kurang } \\
\text { interaktif }\end{array}$ & $\begin{array}{l}\text { - Guru menerapkan metode tanya } \\
\text { jawab untuk meningkatkan } \\
\text { keaktifan peserta didik di dalam } \\
\text { kelas pada saat pembelajaran }\end{array}$ \\
\hline $\begin{array}{l}\text { Peserta didik kesulitan } \\
\text { mengerjakan salah satu } \\
\text { soal dalam LKPD }\end{array}$ & $\begin{array}{l}\text { - Peserta didik } \\
\text { kurang } \\
\text { memahami } \\
\text { materi } \\
\end{array}$ & $\begin{array}{l}\text { - Video pembelajaran ditayangkan } \\
\text { berulang-ulang agar peserta didik } \\
\text { paham }\end{array}$ \\
\hline \multicolumn{3}{|l|}{ Kelas Daring } \\
\hline $\begin{array}{l}\text { Peserta didik kurang } \\
\text { merespon dalam } \\
\text { WhatsApp grup }\end{array}$ & $\begin{array}{ll}\text { - } & \text { Peserta didik } \\
& \text { kurang motivasi }\end{array}$ & $\begin{array}{l}\text { - Guru memberikan motivasi agar } \\
\text { lebih responsif dalam pembelajaran } \\
\text { daring melalui grup WhatsApp }\end{array}$ \\
\hline $\begin{array}{l}\text { Peserta didik terlambat } \\
\text { dalam pengumpulan } \\
\text { LKPD dan latihan soal }\end{array}$ & $\begin{array}{l}\text { - Peserta didik } \\
\text { kesulitan } \\
\text { memahami } \\
\text { materi yang } \\
\text { diberikan }\end{array}$ & $\begin{array}{l}\text { - Guru meminta peserta didik untuk } \\
\text { memutar video pembelajaran } \\
\text { berulang-ulang agar peserta didik } \\
\text { menjadi lebih paham }\end{array}$ \\
\hline
\end{tabular}


Siklus II

Siklus II dilakukan dalam dua kali pertemuan yaitu pada rabu tanggal 31 Maret 2021 membahas materi sifat turunan dan rabu 7 April 2021 membahas aturan rantai. Proses pembelajaran pada siklus II hampir sama dengan siklus I hanya saja terdapat perbaikan tindakan berdasarkan hasil refleksi siklus I. Pada siklus II pembelajaran split class masih dibagi menjadi dua bagian yaitu kelas luring dan kelas daring. Untuk kelas luring pembelajaran yang dilakukan didalam kelas secara tatap muka menggunakan fase-fase pembelajaran langsung sedangkan pada kelas daring dilakukan secara online melalui WhatsApp grup kelas dengan cara mengirimkan link video dan LKPD kepada peserta didik.

Proses pembelajaran pada kelas luring pertemuan ketiga dan keempat dilakukan sesuai sintaks pembelajaran langsung yaitu yang langkah pertama menyampaikan tujuan dan mempersiapkan peserta didik, kegiatan yang dilakukan pada langkah pertama yaitu dengan apersepsi dan motivasi serta menjelaskan informasi tentang materi, latar belakang, tujuan pembelajaran dan mempersiapkan peserta didik untuk belajar. Langkah kedua yaitu Mendemonstrasikan pengetahuan dan keterampilan dengan video interaktif turunan. Pada langkah kedua ini peserta didik mengamati video interaktif tentang turunan yang suda dipersiapkan oleh guru, video pembelajaran tersebut berisi tentang masalah kontekstual tentang turunan,penjelasan materi definisi dan sifat turunan serta contoh soal dan latihan soal. Langkah ketiga yaitu membimbing pelatihan, diawali dengan memberikan LKPD terbimbing kepada tiap kelompok. Guru memberikan bimbingan kepada masing-masing kelompok yang memerlukan bimbingan. Langkah keempat mengecek pemahaman dan memberi umpan balik dilakukan dengan Mengecek hasil diskusi kelompok peserta didik dalam menyelesaikan LKPD apakah sudah melaksanakan tugas dengan baik atau belum. Selanjutnya memberikan kesempatan kepada perwakilan masingmasing kelompok untuk mempresentasikan hasil diskusi pengerjaan LKPD. Kelompok yang lain memberikan tanggapan pada presentasi. Langkah terakhir yaitu memberikan kesempatan untuk pelatihan/bimbingan lanjutan. Bimbingan lanjutan dilakukan jika peserta didik masih mengalami kesulitan tentang materi definisi turunan dan sifatnya. Langkah pembelajaran luring pada pertemuan keempat sama dengan langkah pembelajaran pertemuan ketiga.

Proses pembelajaran pada kelas daring pertemuan ketiga dilakukan melalui whatsApp grup kelas diawali dengan memberikan motivasi kepada peserta didik untuk tetap semangat meskipun pembelajaran dilakukan secara daring serta meminta siswa untuk lebih responsif dalam pembelajaran daring. Selanjutnya guru memberikan informasi tentang materi yang akan dipelajari dan membagikan link video yang sebelumnya sudah diunggah melalui youtube. Guru memberikan kesempatan untuk bertanya jika ada materi, contoh soal atau latihan soal yang masih belum dimengerti pada video pembelajaran. Guru meminta peserta didik untuk memutar video berulang-ulang agar lebih memahami materi. Jika tidak ada pertanyaan maka peserta didik melanjutkan dengan mengerjakan LKPD yang sudah dikirim melalui WhatsApp secara mandiri. Hasil pekerjaan peserta didik berupa LKPD dan latihan soal kemudian difoto dan dikirimkan kepada guru melalui WhatsApp. Langkah pembelajaran daring pada pertemuan kedua sama dengan langkahlangkah pada pertemuan pertama

Secara garis besar proses pembelajaran siklus II pada split class tidak banyak mengalami banyak kendala jika dibandingkan siklus I. Pada kelas daring siswa lebih responsif dan bertanya jika ada yang belum dimengerti, peserta didik sudah tepat waktu dalam mengumpulkan tugas baik LKPD maupun soal tes individu. Pada kelas luring pembelajaran berjalan sesuai rencana dan sintaks pembelajaran langsung, peserta didik mulai percaya diri dengan hasil pekerjaan tes individu serta lebih aktif dalam kegiatan diskusi dan presentasi. Dari 4 soal dalam LKPD tiap kelompok sudah bisa menjawab dengan benar hampir $80 \%$ 
hal tersebut karena peserta didik sudah memahami materi karena penanyangan video dilakukan secara berulang-ulang.

Pada akhir pertemuan keempat dilakukan tes akhir siklus untuk mengetahui hasil belajar peserta didik pada siklus II baik dalam kelas daring maupun luring, tes akhir siklus berupa soal uraian sehingga dapat mengukur tingkat pemahaman peserta didik. Berdasarkan hasil tes akhir siklus dan hasil observasi diperoleh hasil sebagai berikut:

Tabel 4. Hasil Belajar dan Keterlaksanaan Pembelajaran Siklus II

\begin{tabular}{lc}
\hline Nilai terendah & 70 \\
\hline Nilai tertinggi & 92 \\
\hline Jumlah peserta didik belum tuntas & 20 \\
\hline Jumlah peserta didik belum tuntas & 3 \\
\hline Rata-rata & 85,2 \\
\hline Persentase ketuntasan belajar & $86,9 \%$ \\
\hline Persentase keterlaksanaan pembelajaran & $95 \%$ \\
\hline
\end{tabular}

Berdasarkan hasil observasi keterlaksanaan pembelajaran siklus I dan siklus II diperoleh data persentase keterlaksanaan pembelajaran keduanya dengan keriteria sangat baik dan mengalami peningkatan dari siklus I ke Siklus II yaitu sebesar 30\%. Sedangkan hasil belajar peserta didik pada siklus I dan siklus II mengalami peningkatan ketuntasan belajar sebesar $21,7 \%$. Rata-rata hasil belajar peserta didik mengami peningkatan dari 74,5 menjadi 85,2 . Oleh karena itu dapat dinyatakan bahwa kegiatan pembelajaran langsung berbantuan video pembelajaran turunan pada split class terlaksana dengan sangat baik. Dapat disimpulkan bahwa penggunaan video pembelajaran sangat efektif dalam meningkatkan hasil belajar

\section{Pembahasan}

Pembelajaran langsung dengan bantuan video Pembelajaran yang dilakukan pada siklus I dan siklus II menggunakan sintaks modifikasi model pembelajaran langsung yaitu 1) menyampaikan tujuan dan mempersiapkan peserta didik; 2) Mendemontrasikan pengetahuan dan keterampilan dengan video interaktif turunan; 3) membimbing pelatihan 4) mengecek pemahaman dan umpan balik dan 5) Memberikan kesempatan untuk pelatihan lanjutan. Adapun tampilan salah satu video pada sintaks ketiga adalah seperti gambar berikut:

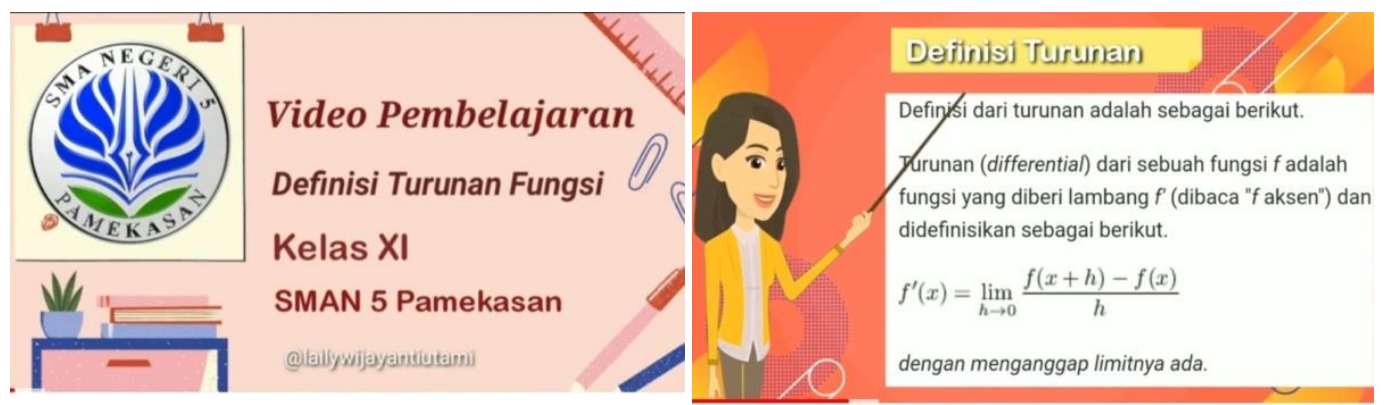

Gambar 1. Tampilan Video Definisi Turunan

Berdasarkan hasil observasi keterlaksanaan pembelajaran siklus I dan siklus II diperoleh data persentase keterlaksanaan pembelajaran keduanya dengan keriteria sangat baik dan mengalami peningkatan dari siklus I ke Siklus II yaitu sebesar 30\%. Sedangkan hasil belajar peserta didik pada siklus I dan siklus II mengalami peningkatan ketuntasan belajar sebesar 21,7\%. Rata-rata hasil belajar 
peserta didik mengami peningkatan dari 74,5 menjadi 85,2 . Oleh karena itu dapat dinyatakan bahwa kegiatan pembelajaran langsung berbantuan video pembelajaran turunan pada split class terlaksana dengan sangat baik. Sehingga dapat disimpulkan bahwa penggunaan video pembelajaran sangat efektif dalam meningkatkan hasil belajar.

\section{Simpulan dan Saran Simpulan} penelitian tentang pelaksanaan pembelajaran langsung dengan media video pembelajaran pada materi turunan fungsi kelas XI MIPA 1 SMA Negeri 5 Pamekasan, maka diperoleh kesimpulan bahwa pembelajaran langsung berbantuan video interaktif turunan yang meningkatkan hasil belajar materi turunan dilakukan dengan langkah: (1) Menyampaikan tujuan dan mempersiapkan peserta didik (2) Mendemonstrasikan pengetahuan dan keterampilan dengan video pembelajaran interaktif turunan (3) Membimbing pelatihan dengan LKPD terbimbing (4) Mengecek pemahaman dan memberikan umpan balik dan (5) Memberikan kesempatan untuk pelatihan lanjutan dan penerapan. Dari penerapan pembelajaran langsung berbantuan video pembelajaran turunan, persentasi ketuntasan belajar peserta didik mengalami peningkatan dari siklus 1 ke siklus 2 dari $65,2 \%$ menjadi $86,9 \%, 2$ sedangkan persentase hasil observasi ketercapaian pelaksanaan pembelajaran mengalami peningkatan sebesar $15 \%$ dengan kriteria pada masingmasing siklus bernilai sangat baik .

\section{Saran}

Dari kesimpulan yang diperoleh diatas, peneliti memberikan saran terkait pembelajaran langsung dengan menggunakan media video antara lain: Media pembelajaran berupa media video dapat dijadikan sebagai salah satu media yang dapat membantu guru dalam proses belajar mengajar agar proses pembelajaran dapat lebih menarik dan inovatif, dan agar penyampaian pesan dalam pembelajaran dapat lebih jelas. Penerapan model pembelajaran langsung menggunakan media video dapat digunakan menuntaskan hasil belajar siswa, sehingga model pembelajaran langsung dengan media video ini dapat ditetapkan pada mata pelajaran lain yang sesuai.

\section{Daftar Pustaka}

Adesote, S. A., \& Fatoki, O. R. (2013). The role of ICT in the teaching and learning of history in the 21st century. Educational Research and Reviews, 8(21), 2155-2159.

Altunisik, R. (2013). The Role of Lecturer Related Factors in Students' Perceptions and Satisfaction in Distance Education. Procedia - Social and Behavioral Sciences, 106, 30753083.

https://doi.org/10.1016/j.sbspro.2013. 12.355

Aniq, B., \& Karyaningrum, A. E. (2018). Penerapan Model Pembelajaran TPS Dengan Media Video Untuk Meningkatkan Hasil Belajar Pembuatan Pola Blus Di SMKN 8 Surabaya. Jurnal Tata Busana, 07, 13-17.

Ardiansah, F. (2018). Pengaruh Penggunaan Media Video Terhadap Minat dan Hasil Belajar Siswa Kelas XI pada Pelajaran PAI di SMA YPI Tunas Bangsa Palembang. Tarbawy: Jurnal Pendidikan Islam, 5(1), 56-70. https://doi.org/10.32923/tarbawy.v5i1. 833

Bravo, E., Amante, B., Simo, P., Enache, M., \& Fernandez, V. (2011). Video as a new teaching tool to increase student motivation. 2011 IEEE Global Engineering Education Conference, EDUCON 2011, 638-642. https://doi.org/10.1109/EDUCON.201 1.5773205

Dzara, K., Chen, D. T., Haidet, P., Murray, H., Tackett, S., \& Chisolm, M. S. (2020). The Effective Use of Videos in Medical Education. Academic 
Medicine: Journal of the Association of American Medical Colleges, 95(6), 970.

https://doi.org/10.1097/ACM.0000000 000003056

Fimansyah, D. (2015). Pengaruh Strategi pembelajaran dan minat belajar terhadap hasil belajar matematika. Judika (Jurnal Pendidikan UNSIKA), $3(1)$.

Fish, K., Mun, J., \& A'Jontue, R. A. (2016). Do visual aids really matter? A comparison of student evaluations before and after embedding visuals into video lectures. Journal of Educators Online, 13(1), 194-217. https://doi.org/10.9743/JEO.2016.1.1

Iza, N. (2014). Penerapan Model Pembelajaran Langsung Dengan Video Untuk Meningkatkan Hasil Belajar Siswa Pada Materi Membuat Pola Celana di SMK Negeri 1 Baureno-Bojonegoro. Jurnal Tata Busana, 3(3).

Julianto, S. (2011). Teori dan Implementasi Model-Model Pembelajaran Inovatif. Surabaya: UNESA.

Khairani, M., Sutisna, S., \& Suyanto, S. (2019). Studi meta-analisis pengaruh video pembelajaran terhadap hasil belajar peserta didik. Jurnal Biolokus: Jurnal Penelitian Pendidikan Biologi Dan Biologi, 2(1), 158-166.

Kustandi, C., \& Sutjipto, B. (2013). Media Pendidikan Manual dan Digital. Bogor: Ghalia Indonesia.

Miftahussurur, M., \& Pramono, P. (2016). Peningkatkan Hasil Belajar Menggunakan Media Video Pembelajaran Pada Kompetensi Dasar Memelihara/Servis Sistem Pendingin Mesin. Jurnal Pendidikan Teknik Mesin Unnes, 16(1), 126234.

Munadi, Y. (2013). Media Pembelajaran. Jakarta: Referensi. GP press group.
Muslina, M. (2017). Upaya Meningkatkan Pemahaman Konsep Matematis Siswa Kelas 2 Sdn 133 Pekanbaru Melalui Penerapan Model Pembelajaran Langsung (Direct Learning). Jurnal Cendekia: Jurnal Pendidikan Matematika, 1(2), 92-99. https://doi.org/10.31004/cendekia.v1i 2.60

Nur, M. (2011). Model Pembelajaran Langsung. Pusat Sains dan Matematika sekolah Unesa.

Nurrita, T. (2018). Pengembangan media pembelajaran untuk meningkatkan hasil belajar siswa. MISYKAT: Jurnal Ilmu-Ilmu Al-Quran, Hadist, Syari'ah Dan Tarbiyah, 3(1), 171.

Panjaitan, D. J. (2017). Meningkatkan hasil belajar siswa dengan metode pembelajaran langsung. Jurnal Mathematic Paedagogic, 1(1), 83-90.

Sugita, G. (2020). PENERAPAN MODEL PEMBELAJARAN LANGSUNG UNTUK MENINGKATKAN KETERAMPILAN SISWA PADA MATERI MELUKIS SUDUT KELAS VII SMP SWADAYA PALU. Jurnal Elektronik Pendidikan Matematika Tadulako, 8(1), 82-93.

Sutjiningtyas. (2018). Penerapan Model Pembelajaran Langsung Untuk Meningkatkan Hasil Belajar Ipa Siswa Kelas Vi Sekolah Dasar. Primary: Jurnal Pendidikan Guru Sekolah Dasar, $\quad 7(1), \quad 122$. https://doi.org/10.33578/jpfkip.v7i1.5 386

Tasmalina, T., \& Prabowo, P. (2018). Pengaruh Media Video Pembelajaran Terhadap Hasil Belajar Siswa Pada Sub Materi Spermatophyta di SMA Swasta Nurul Amaliyah Tanjung Morawa Tahun Pembelajaran 2015/2016. Best Journal (Biology Education, Sains and Technology), 1(1), 14-20. 
https://doi.org/10.30743/best.v1i1.621

Winanto, A., Bennu, S., \& Hasbi, M. (2015). Penerapan model pembelajaran langsung untuk meningkatkan hasil belajar siswa pada materi operasi aljabar bentuk akar di kelas X MIA 7. Jurnal Elektronik Pendidikan Matematika Tadulako,
2(3), 317-328.

Wulandari, S., Pargito, \& Widodo, S. (2017). Efektivitas Pemanfaatan Video Visual Pembelajaran Dalam Upaya Peningkatan Hasil Belajar. Kemampuan Koneksi Matematis (Tinjauan Terhadap Pendekatan Pembelajaran Savi), 1-11. 